\title{
UV Spectrophotometric Determination of Aripiprazole in Bulk and Pharmaceutical Formulation
}

\author{
R. KALAICHELVI ${ }^{\S} *$, B. THANGABALAN", \\ D. SRINIVASA RAO ${ }^{\S}$ and E. JAYACHANDRAN \\ ${ }^{\S}$ K.C.Reddy Institute of Pharmaceutical Sciences, \\ Jangamguntla Palem, Medikonduru Mandal, Guntur-522 348, India. \\ \#Department of Pharmacy, Donbosco PG College, $5^{\text {th }}$ mile, \\ Vatticherukuru Mandal, Pulladigunta, Guntur-522 017, India. \\ S.C.S. College of Pharmacy, \\ Harapanahalli-583131. Devanagari Dist, Karnataka, India. \\ rkselvi123@rediffmail.com
}

Received 16 June 2009; Accepted 10 August 2009

\begin{abstract}
A simple, sensitive and reproducible spectrophotometric method was developed for the determination of aripiprazole in pure form and in pharmaceutical formulation. It has an absorption maximum at $219 \mathrm{~nm}$ and obeys beer's law in the concentration range $2-10 \mu \mathrm{g} \mathrm{mL}{ }^{-1}$. Results of analysis were validated statistically and by recovery studies. The apparent molar absorptivity and sandell's sensitivity were $5.2 \times 10^{5} \mathrm{~L} \mathrm{~mol}^{-1} \mathrm{~cm}^{-1}$ and $8.4 \times 10^{-3} \mu \mathrm{g} \mathrm{cm}^{-2}$, respectively. The slope and intercept of the equation of the regression line are 0.0035 and 0.1155 respectively. Correlation coefficient was found to be 0.9998. This method is successfully employed for the determination of aripiprazole in pharmaceutical preparation.
\end{abstract}

Keywords: UV Spectrophotometry, Aripiprazole, Tablet analysis.

\section{Introduction}

The chemical name of aripiprazole is 7-(4-(4-2,3-dichlorophenyl) -1-piperazinyl) butoxy)3,4 dihydro carbo styril and is used as antipsychotic drug ${ }^{1}$. The structural formula of aripiprazole is shown in Figure 1. Literature survey reveals that the reported methods were HPLC determination $^{2-5}$ of aripiprazole. Hence need arises to develop a simple, accurate UV method for routine analysis of aripiprazole in formulation. 


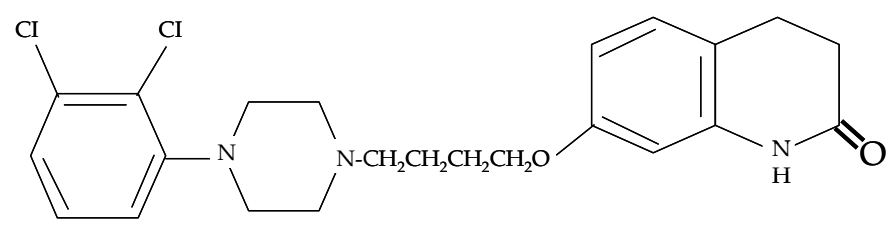

\section{Experimental}

Figure 1. Chemical structure of aripiprazole.

The spectrophotometric measurements were carried out using An Elico UV/Visible double beam spectrophotometer SL-164 with $1 \mathrm{~cm}$ matched quartz cells.

\section{Reagents}

Aripiprazole was tested for purity by measuring its melting point and IR spectra and no impurities were found. Analytical grade methanol was used. A pharmaceutical preparation of aripiprazole was obtained from local pharmacy.

\section{Standard solutions}

Standard stock solution of aripiprazole $\left(1000 \mu \mathrm{g} \mathrm{mL} \mathrm{L}^{-1}\right)$ was prepared in methanol. It was further diluted to obtain $2,4,6,8$ and $10 \mu \mathrm{g} \mathrm{mL} \mathrm{m}^{-1}$ with methanol. The absorbance was measured at $219 \mathrm{~nm}$ against methanol as blank. The calibration curve was plotted in the concentration range of 2 to $10 \mu \mathrm{g} \mathrm{mL} \mathrm{L}^{-1}$ of aripiprazole in methanol.

\section{Procedure for tablets}

Twenty tablets were weighed accurately and triturated to fine powder. The powder equivalent to $100 \mathrm{mg}$ aripiprazole was weighed and transferred to $100 \mathrm{~mL}$ volumetric flask. To this $50 \mathrm{~mL}$ of methanol was added and sonicated for 15 minutes, then filtered through Whatman No. 42 filter paper. The residues were washed thoroughly with methanol and further diluted with methanol to $6 \mu \mathrm{g} \mathrm{mL}^{-1}$ concentration and the absorbance measured at $219 \mathrm{~nm}$ against methanol as a blank.

\section{Results and Discussion}

The UV spectrum of standard solutions of aripiprazole in methanol was illustrated in Figure 2. The optical characteristics such as Beer's Law limit, molar absoptivity, Sandell's sensitivity, slope and intercept are summarized in Table 1. The assay and precision studies results for tablets containing aripiprazole are shown in Table 2.

\section{Validation}

The assay of aripiprazole was validated with respect to stability, linearity, precision and accuracy.

\section{Stability}

The standard stock solutions of aripiprazole were stored, in two different conditions, at $\pm 4{ }^{\circ} \mathrm{C}$ and at ambient temperature for one month. During this period, the solutions were analyzed with UV spectrophotometric method, the spectrum was compared with the spectrum of daily prepared standard solution, and no difference was obtained between them. It is decided that aripiprazole is highly stable in the mentioned conditions.

\section{Linearity and range}

In the developed UV method, calibration curve was linear in the range from 2 to $10 \mu \mathrm{g} \mathrm{mL}^{-1}$ of aripiprazole. 


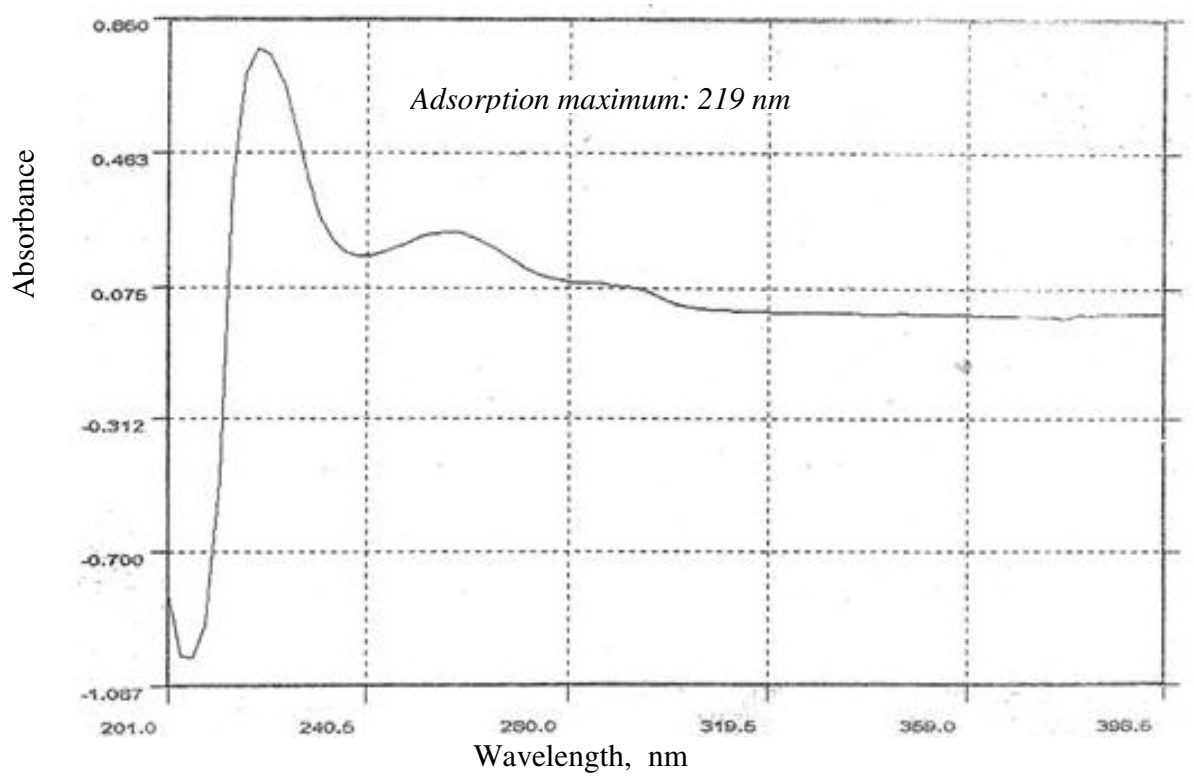

Figure 2. UV spectrum of Aripiprazole in methanol.

Table 1. Optical characteristics of proposed method.

\begin{tabular}{ll}
\hline Parameters & Values \\
\hline$\lambda_{\text {max }} \mathrm{nm}$ & 219 \\
Beer's law limit, $\mu \mathrm{g} \mathrm{mL} \mathrm{m}^{-1}$ & $2-10$ \\
Sandell's sensitivity, $\mu \mathrm{g} \mathrm{cm}^{-2} / 0.001$ absorbance unit & $8.4 \times 10^{-3}$ \\
Molar absorptivity, $\mathrm{L} \mathrm{mol}^{-1} \mathrm{~cm}^{-1}$ & $5.2 \times 10^{5}$ \\
Regression equation $(\mathrm{Y}=\mathrm{a}+\mathrm{bc})$ & \\
Slope (b) & 0.0035 \\
Intercept(a) & 0.1155 \\
Correlation coefficient $\left(\mathrm{r}^{2}\right)$ & 0.9998 \\
\hline
\end{tabular}

Table 2. Assay results and precision studies.

\begin{tabular}{ccccccc}
\hline & \multicolumn{2}{c}{$\begin{array}{c}\text { Labeled amount, Amount found } \\
\text { Sample }\end{array}$} & $\mathrm{mg} / \mathrm{tab}$ & $\begin{array}{c}\% \text { label } \\
\text { in mg* }\end{array}$ & \multicolumn{3}{c}{ Precision** } \\
\cline { 5 - 7 } & claim* \pm S.D & Repeatability & Inter-day & Intra-day \\
\hline $\begin{array}{c}\text { Ariprazole } \\
\text { Tablets }\end{array}$ & 30 & $30.17 \pm 0.148$ & $100.21 \pm 0.315$ & 0.435 & 0.035 & 0.0301 \\
\hline
\end{tabular}

Precision

Inter-day precision: This was done by analyzing formulation for six days subsequently. The $\%$ RSD values are shown in Table 2.

\section{Intra-day precision}

This was done by analyzing formulation in same day for six times of individual preparation and observation. The \% RSD and datas are shown in Table 2. 


\section{Recovery Studies}

Recovery studies were carried out by adding a known quantity of pure drug to a preanalysed formulations and the proposed method was followed. The results of analysis and recovery studies are presented in Table 3 . The percentage recovery values indicated that there is no interference from the excipient(s) present in the formulation. The developed method found to be sensitive, accurate, precise and most reproducible and can be used for the routine quality control analysis of aripiprazole in bulk drug and its formulation.

Table 3. Recovery study.

\begin{tabular}{ccccccc}
\hline Drug & $\begin{array}{c}\text { Label claim, } \\
\mathrm{mg} / \mathrm{tab}\end{array}$ & $\begin{array}{c}\text { Estimated } \\
\text { amount, } \\
\mathrm{mg} / \mathrm{tab}\end{array}$ & $\begin{array}{c}\text { Spike } \\
\text { level, \% }\end{array}$ & $\begin{array}{c}\text { Amount of } \\
\text { drug added, } \\
\mathrm{mg}\end{array}$ & $\begin{array}{c}\text { Amount } \\
\text { of drug } \\
\text { recovered, } \mathrm{mg}\end{array}$ & $\begin{array}{c}\text { Percentage } \\
\text { recovery } \\
\pm \text { SD* }\end{array}$ \\
\hline $\begin{array}{c}\text { Ariprazole } \\
\text { Tablets }\end{array}$ & \multirow{2}{*}{30} & $30.17 \pm$ & 100 & 3.0 & 3.01 & $100.32 \pm 0.4432$ \\
\hline
\end{tabular}

*Mean of six determinations.

\section{Conclusion}

The proposed method is found to be rapid, precise, accurate and sensitive. The statistical parameters and recovery study data clearly indicate the reproducibility and accuracy of this method. Analysis of the authentic sample containing aripiprazole showed no interference from the common excipients. Hence, these methods could be considered for the determination of aripiprazole in the quality control laboratories.

\section{References}

1. Merck Index, An Encyclopedia of Chemicals and Pharmaceuticals, Merk \&Co Inc Whitehouse station, 2005, $13^{\text {th }}$ Edn., pp 1095.

2. Shimokawa Y, Akiyama H and Kashiyama E, J Chromatogr B Anal Technol Biomed Life Sci., 2005, 821, 8.

3. Vijaya Kumar M and Muley P R, Indian Pharmacist., 2005, 71, 4.

4. Katrin krischbaum M and Matthias Muller, J Clinical Chem., 2005, 1718, 51.

5. Krichherr H and Kuhn-Velten W N, J Chromatogr B Anal Technol Biomed Life Sci., 2006, 843, 100 . 


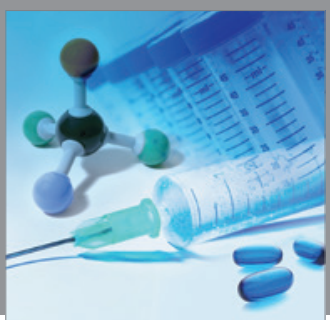

International Journal of

Medicinal Chemistry

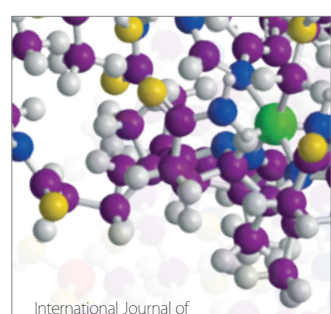

Carbohydrate Chemistry

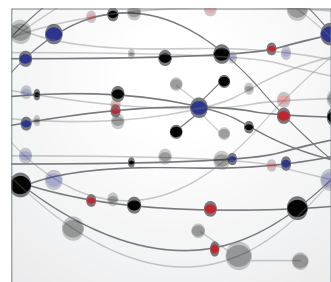

The Scientific World Journal
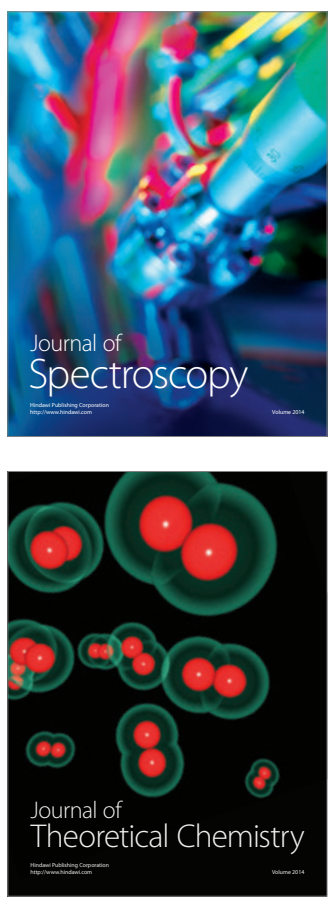
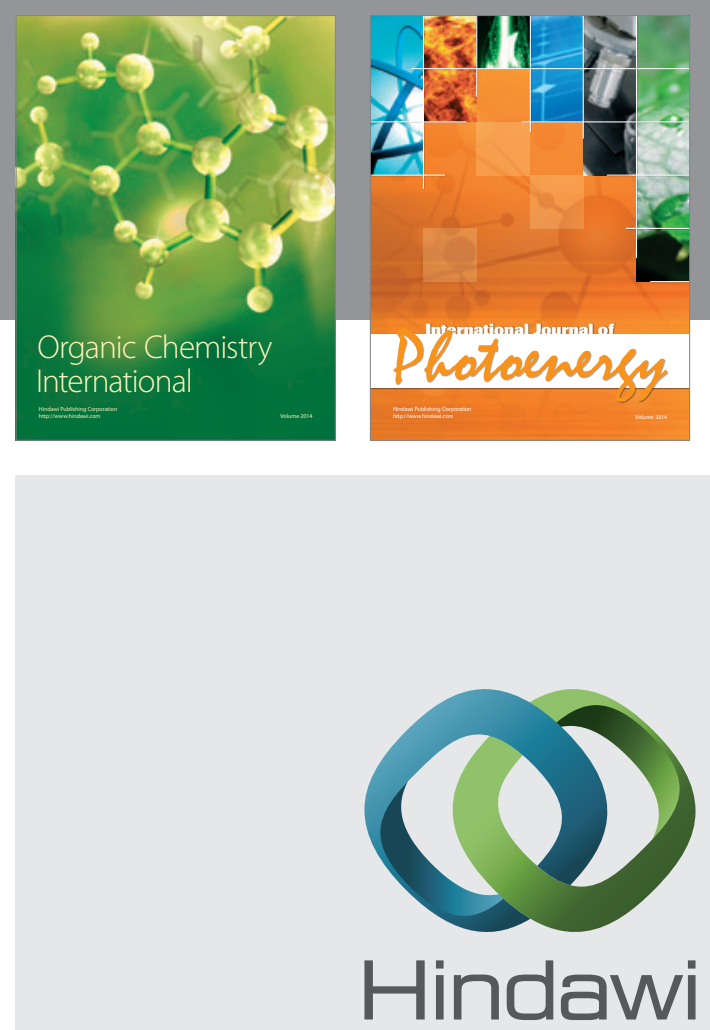

Submit your manuscripts at

http://www.hindawi.com
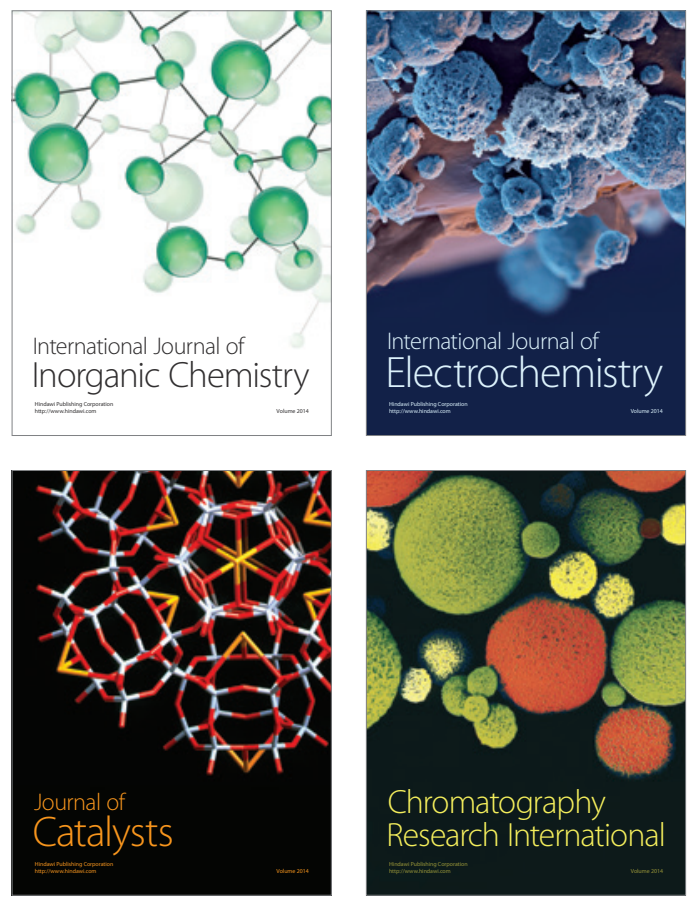
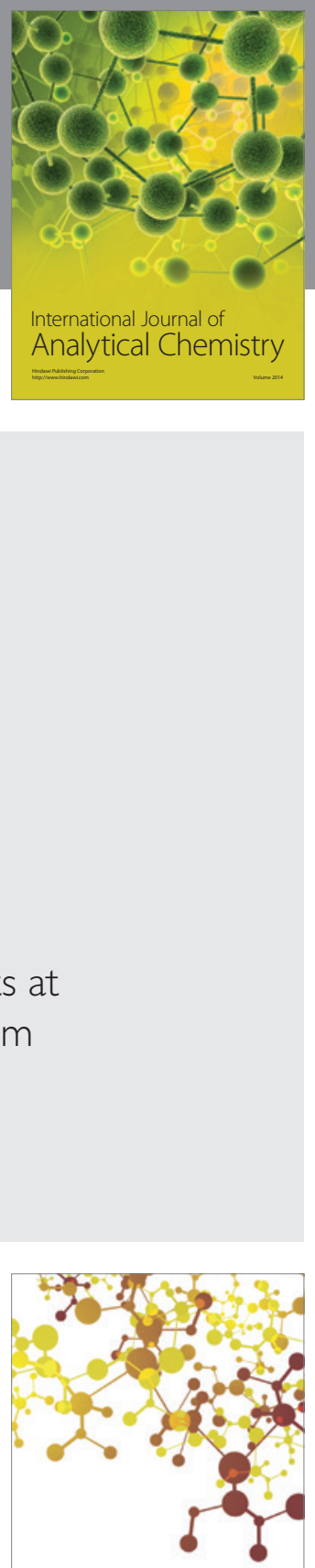

Journal of

Applied Chemistry
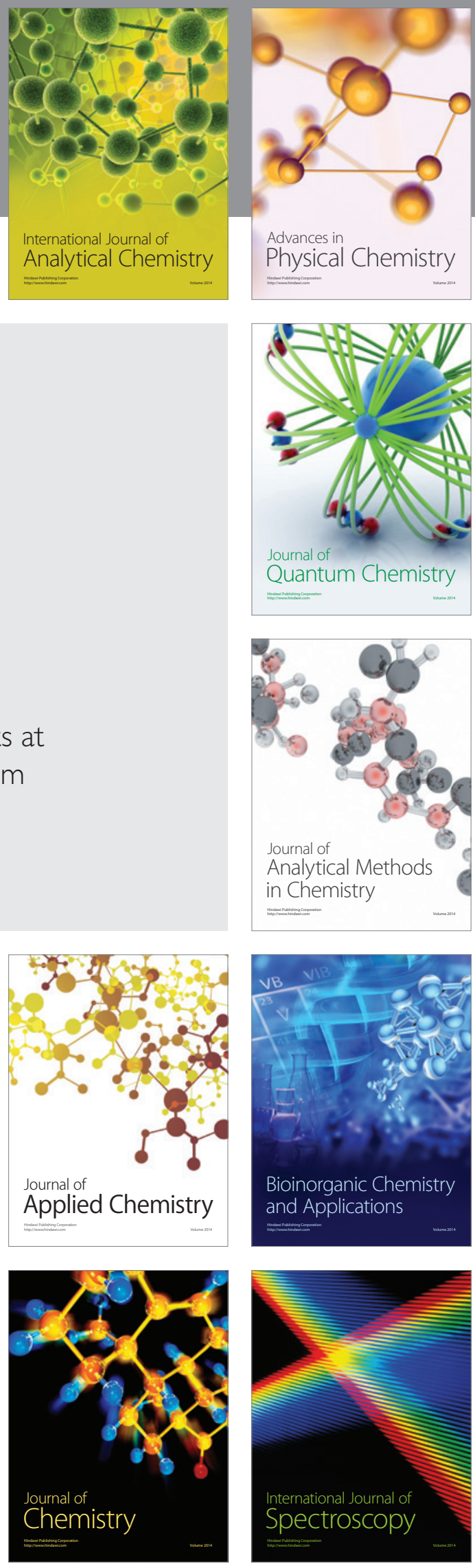